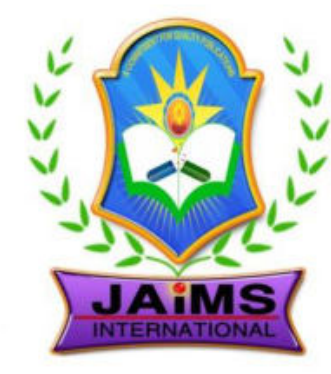

ISSN 2456-3110

Vol $5 \cdot$ Issue 1

Jan-Feb 2020

Journal of

Ayurveda and Integrated Medical Sciences

www.jaims.in

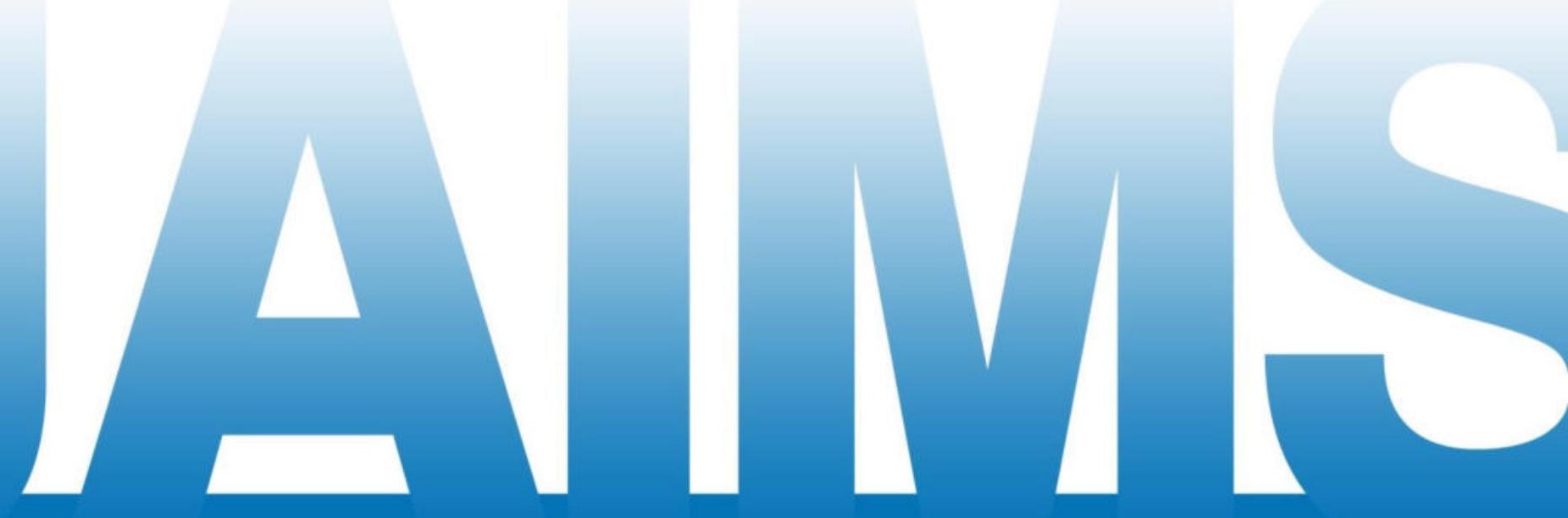

An International Journal for Researches in Ayurveda and Allied Sciences

\title{
Charaka
}




\title{
Ayurveda and Integrated Medical Sciences
}

\section{An open labeled clinical trail on the effect of Vrikshamla in Sthaulya (obesity) w.s.r to hyperlipidaemia}

\author{
Dr. Ishwarayya S. Mathapati ${ }^{1}$, Dr. Manu $\mathbf{R}^{2}$ \\ ${ }^{1}$ Ph.D Scholor, ${ }^{2}$ Professor \& H.O.D., Department of Kayachikitsa, Parul University, Limda, Waghodiya, Vadodara, \\ Gujarat, INDIA.
}

\section{A B S TRACT}

\begin{abstract}
Obesity is one of the leading cause for more than 53 diseases and in India around 30 million peoples are suffering with Sthaulya (obesity), individual habits with stressful life, wrong dietary habits and sedentary life is the main cause of disease and no satisfactory treatment is available in conventional system. Hence there is need explore alternative system of Indian medicine like Ayurveda for the benefits of sufferers Ayurveda dealt this disease as Sthaulya (obesity) under Medoroga (Adipose tissue disorder) and many treatment modalities have been explained number of drugs in Brahatrayi (Charaka, Sushruta \& Vagbhat) were cited Bhavamishra was the author of Bhavaprakash Nighantu (Lexicon) which is one of the Laghutrayis (Sharanghadara, Madhavanidhana \& Bhavaprakash) text is highlighted with Karmaoushadi (action based drug) such as Amradi Phala Varga explained Vrikshamla considered as drug index of Ayurveda, thus present study was designed to screen the drug with properties of Kapha Medohara (ability to reduce Kapha \& Fat), Medorogahara (reduces Adipose tissue), Sthaulyanashaka (Anti obesity) and Karshyakara (ability to make lean) from Bhavaprakasha Nighantu in Ayurveda.
\end{abstract}

Key words: Obesity, Sthaulya, Vikshamla, Bhavaprakasha Nighantu, Ayurveda.

\section{INTRODUCTION}

Ancient Indian vedic thought has now become globally acceptable with its universal terminology. Ayurveda believes that human being is a epitome of universe. And is basically composed of same elements that are known as five basic elements, namely Prithvi, Aap, Teja, Vayu and Akasha, all the five elements are called as Panchamahabhuta, around the axis of Panchamahabhuta the three pillers of life are revolved. Ayurveda is based on the principle of

\section{Address for correspondence:}

Dr. Ishwarayya S. Mathapati

Ph.D. Scholor, Department of Kayachikitsa, Parul University,

Limda, Waghodiya, Vadodara, Gujarat, INDIA.

E-mail: dr.ishwar.mathapati@gmail.com

Submission Date: 09/01/2020

Accepted Date: $13 / 02 / 2020$

Quick Response Code

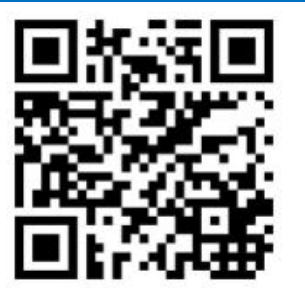

Tridoshas Vata, Pitta and kapha, these tridoshas are the basic constituents of the physiological system, these tridoshas are basic metabolic elements constituting the body and mind of the living organisms. As we moved into rapid modernization by providing almost luxury to our day- to- day life, an average of person is unable to maintain individual's health by not adopting proper dietery and daily activities as a result of which many diseases such as Sthaulya or Medoroga/Hyperlipidemia occur. Therefore Hyperlipidemia may be correlated with the conditions of Santarpana-janya-vikara as explained in our classics (Ch.Su.23 ${ }^{\text {rd }}$ ). So for Concept of Hyperlipidaemia is the excess accumulation of lipids (Especially plasma lipids) in the body, leading various acute or chronic condition. "Ayurveda classics have also referred that "Prayaha-SnehatmedahaPravardhayet" (M.Ni-34/3-4), Implying the fact that excess Sneha is responsible for excess production of Meda and such excessively produced meda causing avarodha or avarana of other, Dhatu leading to Medoroga/Sthaulya-laxana as well as upadrava, here 
we can link the vikruti which is explained in Ayurveda with present modern knowledge about lipids. Therefore need and relevance of proposed research study for obesity/ Hyperlipidaemia is a common disorders of recent days, it affects about $25 \%$ of total population, mostly the people of developed countries as well as developing countries are said to be suffering from this condition. Blood levels of cholesterol and triglycerides give a valuable information for the assessment of errors in lipidsmetobolism. Various surveys in USA and European countries have shown a definite correlation between a high incidence of coronary heart diseases and raised cholesterol and triglyceride levels in the body, conversely in some estern countries the average of cholesterol level is low, as well as the incidence of coronary heart diseases. In India the incidence of Hyperlipidaemia and related disorders are increasing every year as the evidence of positive correlation between LDL cholesterol and cardiovascular diseases. There is even stronger negative correlation with $\mathrm{HDL}$ higher the plasma HDL level, the lower risk of cardiovascular diseases. Diagnosis of Hyperlipidaemia is done by clinical and laboratory investigations, If Hyperlipidemia is diagnosed the prime aim is to bring back the high cholesterol level to normal levels, the LDL triglycerides and total cholesterol levels should be lowered and HDL level should be increased by diet control and drug therapy which has equal importance in controlling the disease. Impairment of various enzymes is the cause for Hyperlipidaemia, Ayurveda considers that the cause of all these conditions are Agni-vikruti, here Jatharagni, Bhutagni and Dhatwagni are involved. In this regard approach of Ayurveda is more safer. comprehensive and rational. in this present study the drug or medicine is selected Vrikshamla, which is indicated in Sthaulya/ Medovriddhi/ Santarpana- Janya- Vikaras. Accumulation of Ama and vitiated Dhatus are seen in this condition, these drugs have Deepana, Amapachana, Kapha and Meda Shamana, Anulomana properties. Which forcefully clears the accumulated and improper Dhatus and Malas from the Dhatus and removes deposited Malas from the Srotas and make Dhatus and Srotas clear and normal which can be used in this conditions. In the pathology of Sthaulya, Kapha is main Dosha and Meda is main Dushya, while Agnimandya takes place at Medodhatvagni level. So, that type of drug therapy should be selected which have Kapha and Medohara property and have efficacy to correct the function of Medodhatvagnimandya. So many preparations have been mentioned in our texts for the treatment of Medodhatu Vridhi. But keeping in mind easy availability, compatibility, cost and preparation of drug Vriksham/a ${ }^{[8]}$ were preferred and select for present study.

\section{OBJECTIVES OF THE STUdY}

1. To evaluate the therapeutic effect of Vrikshamla in Sthaulya (obesity).

2. To evaluate the therapeutic effect of Vrikshamla in Medoroga / Santarpanajanya-Vikaras.

\section{Materials And Methods}

\section{Inclusion Criteria}

1. Both Males \& females will be selected.

2. Patient will be selected from the age group $20-50$ yrs

3. Lipid profile level

4. Serum ch. Above $-200 \mathrm{mg} / \mathrm{dl}$

5. Serum tri. above $-165 \mathrm{mg} / \mathrm{dl}$

6. LDL above $-150 \mathrm{mg} / \mathrm{dl}$

7. HDL belove $-70 \mathrm{mg} / \mathrm{dl}$

8. Patient of Sthaulya diagnosed according to classical features.

9. Patients with $\mathrm{BMI}$ above -30

\section{Exclusion Criteria}

1. Patients below the age of 20 years and above the 50 years.

2. Patients undergoing other treatment for Sthaulya (obesity).

3. Known cases of Diabetes mellitus (Madhumeha), Hyperthyroidism, Thyrotoxicosis, Nephrotic syndrome, Hypertension, Cardiac patients, Gouty 
arthritis, Infectious diseases, Endocrinal and CNS disorders.

4. Hepatic Disorders

Diagnostic Criteria

Assessment of Subjective Parameters

- Kshudha aadhikya (Excessive hunger)

- Pipasa aadhikya (Excessive thirst)

- Kshudra shwasa (Breathlessness)

- Swedaadhikya (Excessive sweating)

- Atinidra (Excessive sleep)

- Daurbalya (General debility)

- Gaurava (Heaviness of the body)

- Alasya (Letharginess)

- Angasada (Sluggishness of the body)

- Krichchavyavayata (difficulty in sexual intercourse)

Objective Parameters

1. Body weight

2. $\mathrm{BMI}$

3. Body circumference measurements (at upper mid arm, chest, abdomen, waist-hip)

4. Blood pressure

5. Lipid profile Test.

Design of study

- Single Arm trail/ an open clinical trail

- Sample size: 60

- Statistical analysis: Paired ' $\mathrm{t}$ ' test and other appropriate statistical tests will be adopted.

Intervention

Vrikshamla Capsule 500mg BD before meal with luke warm water

Duration of the study

60 days

Follow up

Follow up will be done monthly for 3 consecutive months.

\section{VRIKSHAMLA (GARCINIA CAMBOGIA)}

Botanical Classification
1. Kingdom - Plantae
2. Subkingdom - Tracheobionta
3. Division - Magnoliophyta
4. Class - Magnoliopsida
5. Subclass - Dilleniidae
6. Order - Malpighiales
7. Family - Clusiaceae
8. Genus - Garcinia
9. Species - Garcinia cambogia

\section{Chemical Composition}

The fruits of Vrikshamla contains $10 \%$ maleic acid and very little quantity of tartaric and citric acid. Garcinia is a rich source of active compounds including garcinol, isogarcinol, xanthochymol, isoxanthoehymol and Hydroxy citric acid. These are flavonoids, benzophenones, xanthones, lactones and phenolic acids. Xanthones are oxygenated heterocyclic compounds present in higher plants. Xanthone nucleus is symmetric and is known as xanthen-9Hones or 9- xanthenone or dibenzo-y-pyrone. The biological activities of these compounds depend on the different substituent's position and nature. Flavonoids are polyphenolic compounds, which are remarkable group of plant metabolites. The antioxidant and free radical scavenging activity of flavonoids depend on the position of hydroxyl groups and other chemical features. Benzophenones are organic group of aromatic ketones having the parent compound diarylketone, which have wide applications in pharmaceutical industry as the plant has a wide range of biologically active compounds showing broader activity range.

Ayurvedic Pharmacodynamic

Vrikshamla (Garcinia cambogia)

Rasa : Madhura, Amla, Katu (Amlarasa dominant) 
Guna : Ruksha, Laghu

Virya : Ushna

Vipaka : Amla

Prabhava : Hridya

Doshaghnata : Kapha-Vatahara

Parts Used : Fruits, Seed oil, Root bark

Dose : 2 to $4 \mathrm{gm}$ powder. Fruit Juice-10 to $20 \mathrm{ml}$,

Fruit extract - The usual dose of Garcinia extract is 300 to 500mg BD before meal with water.

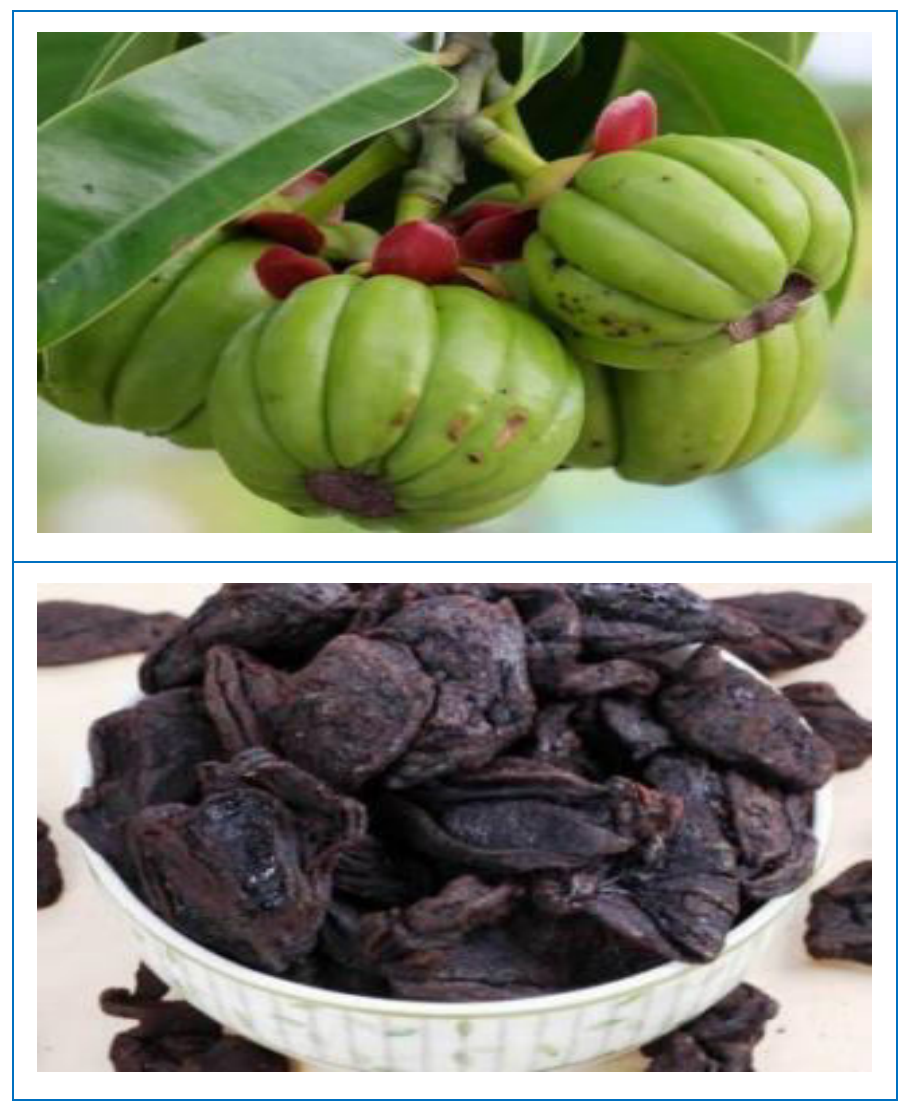

Vrikshamla (Extract)

The extract (water based) of Vrikshamla fruits has Amla, Katu and Madhura Rasa. It also has Laghu and Ushna Guna with predominance of Vayu and Agni Mahabhuta. The Deepana, Pachana and KaphaMedohara properties of Vrikshamla are also mentioned in Ayurvedic literature. Due to its Laghu and Ushna Guna it digest the Amasanchaya and clears the Srotorodha. It contains mainly Amla Rasa which has the property of Agnideepana also predominance of Vayu and Agni Mahabhuta makes it Laghu Dravya having inherent tendency of Agnisamdhukshana (Ch.Su.-5/6). So on the basis of these factors it is quite acceptable that Vrikshamla digest the Amasanchaya, clears the Srotorodha and improves the status of Jatharagni and Dhatvagni. Moreover modern science has also shown interest in Vrikshamla. Many studies have shown that intake of HCA present in Kokam reduces appetite, inhibits lipogenes is and reduces body weight.

\section{Assessment Criteria}

\section{Clinical Gradings (Subjective Parameters)}

In the present clinical study all the cases of Sthaulya (obesity) will be assessed with the specific subjective and objective parameters at a regular interval of 15 days.

All the above symptomatic assessment will be done by using Symptom Rating Scale as following:

\begin{tabular}{|l|l|}
\hline Symptoms & Score \\
\hline Absent & 0 \\
\hline Mild (Irregular) & 1 \\
\hline Mild (Regular) & 2 \\
\hline Moderate & 3 \\
\hline Severe & 4 \\
\hline
\end{tabular}

Assessment of Subjective Parameters

- Assessment of Kshudha aadhikya (Excessive hunger)

\begin{tabular}{|l|}
\hline 0 - becomes hungry after about $6 \mathrm{hrs}$ \\
\hline 1 - becomes hungry after about $4-5 \mathrm{hrs}$ \\
\hline 2 - becomes hungry after about $3 \mathrm{hrs}$ \\
\hline 3 - becomes hungry after about 2 -3hrs \\
\hline 4 - becomes hungry after about $2 \mathrm{hrs}$ \\
\hline
\end{tabular}

- Assessment of Pipasa aadhikya (Excessive thirst)

0 - Drinks about 8-10 glass of water daily

1 - Drinks about 10-15 glass of water daily

2 - Drinks about $15-20$ glass of water daily

3 - Drinks about 20-25 glass of water daily 
4 - Unable to have a sound sleep for his thirst

- Assessment of Kshudra shwasa (Breathlessness)

0 - No shortness of breath

1 - Mild dyspnoea after physical exertion relieved on rest

2 - Moderate dyspnoea after physical exertion

3 - Dyspnoea even after daily routine

4 - Breathless even at rest

- Assessment of Swedaadhikya (Excessive sweating)

0 - Normal perspiration

1 - Mild perspiration after doing exertion

2 - Increased perspiration after doing little exertion

3 - Profuse perspiration after doing little exertion

4 - Perspiration without exertion

- Assessment of Atinidra (Excessive sleep)

0 - 6-8 hrs/day sleep

1 - 8-10hrs/day sleep

2 - 10-12 hrs/day sleep

3 - 12-14 hrs/day sleep

4 - >14 hrs/day sleep

- Assessment of Daurbalya (General debility)

0 - Feeling of well being

1 - Tired after doing strenuous physical activity

2 - Tired after doing moderate physical activity but can do daily activity

3 - Perform daily activity with difficulty

4 - Extremely tired to carry out daily routine activity

- Assessment of Gaurava (Heaviness of the body)

0 - No feeling of heaviness.

1 - Occasional feeling of heaviness.
2 - Continuous feeling of heaviness, but patient does usual work.

3 - Continuous feeling of heaviness which hampers usual work.

4 - Unable to do any work due to heaviness.

\section{DISCUSSION}

\section{Probable mode of action of drug}

In Ayurveda the action of drug is determined on pharmacodynamic factors as Rasa-Guna-Veerya and Vipaka along with certain specific properties called as prabhava (Karma) Vrikshamla (Extract): The extract (water based) of Vrikshamla fruits has Amla, Katu and Madhura Rasa. It also has Laghu and Ushna Guna with predominance of Vayu and Agni Mahabhuta. The Deepana, Pachana and Kapha-Medohara properties of Vrikshamla are also mentioned in Ayurvedic literature. Due to its Laghu and Ushna Guna it digest the Amasanchaya and clears the Srotorodha. It contains mainly Amla Rasa which has the property of Agnideepana also predominance of Vayu and Agni Mahabhuta makes it Laghu Dravya having inherent tendency of Agnisamdhukshana (Ch.Su.-5/6). So on the basis of these factors it is quite acceptable that Vrikshamla digest the Amasanchaya, clears the Srotorodha and improves the status of Jatharagni and Dhatvagni. Moreover modern science has also shown interest in Vrikshamla. Many studies have shown that intake of HCA present in Kokam reduces appetite, inhibits lipogenes is and reduces body weight.

\section{CONCLUSION}

The present review on Anti Obesity drug Vrikshamla mentioned in Bhavaprakasha Nighantu. The management of Sthaulya/Metabolic syndrome in conventional system of medicine is still not satisfactory and warranting newer strategies from other resources, it seems to explore an Ayurveda inspired line of management for treating Sthaulya (Obesity) or Metabolic syndrome and preventing its life threatening complications in the present clinical work Vrikshamla (garcinia combogia) is selected as trail drug for treatment of Sthaulya (Obesity) because of its Medohara (Reduce fat) cardio protective, Anti 
Oxidant and lipid per oxidation, in habitation properties.

\section{REFERENCES}

1. Sushruta Samhita (Edited by Kaviraj Ambika dutta Shastri) Author - Acharya Susrutha Published by Chaukambha Bharati Acadamy, Varanasi. 11th edition 1998.

2. Charaka Samhita (Edited by Vidyotini Hindi Commentary by Kasinath Shastri) Author - Sri Agnivesha and Partisamskarana by Drudabala. Published by - Chaukambha Bharati Acadamy, Varanasi. 22nd Edition 1996.

3. Astanga Sangraha (Hindi Commentary by Kaviraj Atrideva Gupta) Author - Sri Mada Vagbhata Published by - Krishnadas Acadamy, Varanasi. Reprinted 1993.

4. Astanga Hridaya (Edited by Pt. Bhigachary Harishastri Paradkar Vaidya) Author - Vagbhata Acharya Published by - Krishnadas Acadamy, Varanasi. 10th edition 1987

5. Bhavaprakasha (Vidyotini Hindi Commentary by Sri Harihar Prasad Pandya) Published by - Chaukumba Sanskrit Samsthana, Varanasi. 6th edition 1997.

6. Madhava Nidana (Vidyotini Hindi Commentary by Prof. Yadunandana Upadhyaya) Published by - Chaukumba Sanskrit Samsthana, Varanasi. 7th edition 1999

7. Bhaishajya Ratnavali (Edited by - Sri. Raje,swar datta Shatri) Author - Govinda das Published by - Chaukumba Sanskrit Samsthana, Varanasi. 13th edition 1997.

8. Vrikshamla explained by Charaka samhita -sutra sthana $27^{\text {th }}$ chapter \& Bhava Prakash nighantu Amradi phala varga explained in $6^{\text {th }}$ chapter. 148,149 Dhanvantari Nighantu Shatapushpadi varga 92,Kayadeva Nighantu Aushadhi varga-369, 370. Raja Nighantu Pippalyadi Varga 124.

9. Sharma P V Dravyaguna Vijnana Vol-II $5^{\text {th }}$ chapter Page No. 337 Varanasi, Choukamba Bharathi Academy.

10. Harrisons Principles of Internal Medicine. 15th Edition Editors - Antony S. (Fauci and Eugene Braunwald)

11. Text book of Medical Physiology Edited by Guyton and Hall 9th edition 1996
12. Gami A S, Witt B J Howard D E; Et.al Metabolic syndrome and risk of incident cardio-vascular events and death : a systematic review and meta-analysis of longitudinal studies, J Am Coll Cordiol. 2007; 49, 403414

13. Bentley-Lewis R. Koruda K. Seely EW. The metabolic syndrome in women. Nat ClinPractEndocrinolMetab. Oct 2007;3(10):696-704.

14. Kolovou GD, Anagnostopoulou KK, Salpea KD, et al. The prevalence of metabolic syndrome in various populations. Am J Med Sci. Jun. 2007; 333(6):362-71.

15. World Health Organization."Definition. diagnosis and classification of metabolic syndrome and its complications:Report of a WHO Consultation. Part 1. Diagnosis and classification of metabolic syndrome". http://www. who.int/diabetes/publications/en/. Retrieved 2007-05-29.

16. Grundy SM. Cleeman JI, Daniels SR, et al. Diagnosis and manament of the metabolic syndrome: an American Heart I Association/National Heart, Lung, and Blood Instftute Scientific Statement. Circulation. Oct 25 2005;112(17):2735-52.

17. Dr. Ajai Kumar Pandey. 'Conceptual background of Obesity (Sthaulya/ Medoroga) \& an approach for its management through Ayurveda' (pp.47-60); "Integrative Approach to Metabolic disorders (IAMD)", Published by MRF \& SW. $1^{\text {St }}$ ED., Varanasi, India (20132014), p.no. 47-60.

18. Masullo M, Bassarello C. Suzuki $H$, et al. Polyisoprenylated Benzophenones and an unusual Polyisoprenylated Tetracyclic Xanthone from the Fruits of Garcinia cambogia, Journal of Agricultural and Food chemistry, 56, 2008, 5205-5210.

How to cite this article: Dr. Ishwarayya S. Mathapati, Dr. Manu R. An open labeled clinical trail on the effect of Vrikshamla in Sthaulya (obesity) w.s.r to hyperlipidaemia. J Ayurveda Integr Med Sci 2020;1:1621.

http://dx.doi.org/10.21760/jaims.5.1.4

Source of Support: Nil, Conflict of Interest: None declared. 